\title{
Impact of human metapneumovirus infection on in and outpatients for the years 2006-2008 in Southern Brazil
}

\author{
Maria C Debur', Luine RR Vidal', Elenice Stroparo', Meri B Nogueira', Sérgio M Almeida', \\ Gislene A Takahashi', Indianara Rotta', Luciane A Pereira', Clyete S Silveira', \\ Adriana Delfraro², Sueli M Nakatani ${ }^{3}$, Irene Skraba ${ }^{3}$, Sonia M Raboni ${ }^{1 /+}$ \\ 'Laboratório de Virologia, Hospital de Clínicas, Universidade Federal do Paraná, Rua Padre Camargo 280 sala 202, 82060-240 Curitiba, PR, Brasil \\ ${ }^{2}$ Sección Virología, Facultad de Ciencias, Universidad de la República, Montevideo, Uruguay \\ ${ }^{3}$ Laboratório Central de Saúde Pública, Curitiba, PR, Brasil
}

The human metapneumovirus (hMPV), member of the Paramyxoviridae family, has been reported as an important agent involved with acute respiratory infections (ARIs). The aim of this study is to identify hMPV as the etiological agent of ARIs on in and outpatients in the city of Curitiba, Southern Brazil, and describe clinical data of hMPV subtyping. A retrospective study was performed in 1,572 respiratory samples over a period of three years. hMPV was detected by reverse transcription-polymerase chain reaction and subtyping was performed by nucleotide sequencing. $h M P V$ was present in 61 (3.9\%) samples and subtypes $A 1, A 2 a, B 1$ and B2 were detected. The incidence of $h M P V$ was higher in outpatients (5.9\%), whose mean age was 19.7 years (range 6 months-75 years old), than in inpatients (3\%), whose mean age was 7.6 months (range 1 month-26 years old). The outpatients had upper respiratory tract infections with flu-like symptoms and all hospitalized children had lower respiratory tract infections. A pediatric patient died from complications associated with hMPV A2a infection. hMPV has been reported as a respiratory pathogen in all age groups. No correlation was observed between viral subtype and disease severity in the samples of this study.

Key words: human metapneumovirus - subtypes - respiratory infection - inpatients - outpatients

Acute respiratory tract infections (ARIs) are an important cause of morbidity and mortality in the world (Alto 2004, Kahn 2006). In Brazil and other countries, viruses have been frequently reported as etiologic agents of ARIs (Alto 2004, Tsuchiya et al. 2005, Costa et al. 2006). Tsuchyia et al. (2005), in a study in Curitiba, state of Paraná (PR), Southern Brazil, identified the most common respiratory viruses [influenza A (FLU A), influenza B (FLU B), respiratory syncytial virus (RSV), adenoviruses $(\mathrm{AdV})$, human parainfluenza viruses 1, 2 and 3 (PIV1, 2 and 3)] as etiological agents in $30 \%$ of the specimens of respiratory tract infection on in and outpatients. However, in a large number of ARIs, the etiological agent is not determined (Tsuchiya et al. 2005, Thomazelli et al. 2007).

Advances in epidemiologic surveillance and molecular biology have allowed the rapid recognition and identification of several newly emerging respiratory pathogens (Alto 2004, Kahn 2006). The human metapneumovirus (hMPV) was first described in 2001 in the Netherlands and was classified in the Paramyxoviridae family (van den Hoogen et al. 2001). Sequence analysis of isolates identified two main genotypes of hMPV, A and B, with the subtypes A1, A2a, A2b, B1 and B2 (Gray et al. 2006, Huck et al. 2006). In Brazil, the subtypes A1, A2a, B1 and B2 were described circulating during the years 20032006 (Carneiro et al. 2009, Oliveira et al. 2009).

+ Corresponding author: sraboni@ufpr.br

Received 10 May 2010

Accepted 26 August 2010
hMPV has been associated with respiratory disease in several countries throughout the world (Howe 2002, Bastien et al. 2003, Cuevas et al. 2003, Esper et al. 2003, Freymouth et al. 2003, Madhi et al. 2003, Maggi et al. 2003, Peiris et al. 2003, Ebihara et al. 2004, Mirazo et al. 2005, Gray et al. 2006, Debur et al. 2007). The epidemiological characteristics of hMPV infection include respiratory impairment, particularly in children, elderly and immunocompromised patients (van den Hoogen et al. 2004) with clinical symptoms that cannot be distinguished from those associated with other respiratory diseases caused by virus and may cause infections from upper respiratory tract infections to bronchiolitis and pneumonia (Boivin et al. 2002). Common laboratory methods for the diagnosis of respiratory viruses, such as tissue culture and antigen-based assays, have been shown to have low sensitivity and specificity to detect hMPV. A molecular assay, reverse transcription-polymerase chain reaction (RT-PCR), was the first method selected to detect this virus (Mackay et al. 2003, Calicó et al. 2009).

The aim of this study is to present demographic and clinical data from inpatients and outpatients with respiratory infections caused by hMPV subtypes.

\section{PATIENTS, MATERIALS AND METHODS}

Samples - We analyzed nasopharyngeal aspirates (NPAs) from patients with respiratory clinical manifestations admitted to the Teaching Hospital of the Federal University of Paraná (HC-UFPR) and in primary healthcare units that were included in the National Influenza Protocol (Influenza Surveillance Program) in Curitiba, between 2006-2008. 
The samples used in this study from the inpatients of HC-UFPR were obtained from those admitted to different clinical units, such as the Hematopoietic Stem Cell Transplantation (HSCT) and Pediatrics (semi-intensive and intensive care) units to treat ARIs. The samples from outpatients were obtained from those treated in the primary healthcare units who presented with "flulike" clinical manifestations according to the National Influenza Protocol (fever, cough, wheeze, dyspnea, otalgia, myalgia) and the three selection criteria were fever, at least one of the respiratory manifestations and one clinical manifestation.

The NPAs were obtained by aspiration as described by Gardner and McQuillin (1968). The samples were maintained in a transport medium (tryptose phosphate buffer enriched with gelatin) and transported on ice to the virology laboratory. The NPA samples were processed to detect the most common viral antigens, such as RSV, FLU A, FLU B, AdV and PIV, by indirect immunofluorescence assay (IFA) as previously described (Cox et al. 1998), using commercially available monoclonal antibodies (Chemicon International Inc, Temecula, CA). Aliquots of the samples in transport medium were stored at $-70^{\circ} \mathrm{C}$ for use in the RT-PCR assay to detect hMPV.

Detection of the hMPV $N$ gene - Samples added to $1 \mathrm{~mL}$ of viral transport medium kept at $-70^{\circ} \mathrm{C}$ were used for RNA extraction. Total RNA was extracted using a buffer containing guanidine thiocyanate as previously described (Casas et al. 1995). Five hundred copies of pseudorabies virus (PRV) were added to the extraction buffer as an internal control. Complementary DNA (cDNA) was produced using specific N1 primer (5'-ATGGGGACAAGTGAAAATGTC-3') and the Superscript II RT enzyme (Invitrogen, Life Technologies) incubated for $60 \mathrm{~min}$ at $42^{\circ} \mathrm{C}$ according to manufacturer's instructions. cDNA was amplified to detect a $928 \mathrm{bp}$ conserved region of the nucleoprotein $(\mathrm{N})$ gene (positions 112-1040 nt, based on AY297749 sequence). Two microliters of cDNA were used for a $25 \mu \mathrm{L}$ reaction containing the following: $2.5 \mu \mathrm{L} 10 \mathrm{x}$ PCR buffer minus $\mathrm{Mg}$ (Invitrogen, Life Technologies, Carlsbad, CA), $0.75 \mu \mathrm{L}$ $50 \mathrm{mM} \mathrm{MgCl}$ (Invitrogen, Life Technologies, Carlsbad, CA), $5 \mu \mathrm{L} 2.5 \mathrm{mM}$ dNTPs, 10 pmol PRV1-(5'-ATGACGCCGATGTACTTCTTCTT-3'), 10 pmol PRV1+ (5'- CGCGTGGTCTACGGGGACACGGA-3'), 5 pmol N2 (5'-GAGTCTCAGTACACAATAA-3'), 5 pmol N3 (5'-GCATTTCCGAGAACAACAC-3') primers and $1.25 \mathrm{U}$ Taq Polymerase (Invitrogen, Life Technologies, Carlsbad, CA) and the final volume was completed with RNase free distilled water. Cycling conditions were as follows: an initial denaturation step at $94^{\circ} \mathrm{C}$ for $3 \mathrm{~min}$, followed by 50 cycles at $94^{\circ} \mathrm{C}$ for $45 \mathrm{~s}, 50^{\circ} \mathrm{C}$ for $30 \mathrm{~s}$ and $72^{\circ} \mathrm{C}$ for $1 \mathrm{~min}$ and a final extension at $72^{\circ} \mathrm{C}$ for $10 \mathrm{~min}$. PCR products were analyzed by electrophoresis in a $1 \%$ agarose gel stained with ethidium bromide (modified from Mirazo et al. 2005). For reference and quality control, water was included as a negative control and a positive control was generated as described in the study by Debur et al. (2007). RT-PCR was performed in duplicate and samples were considered to be positive if both reactions were positive.
Detection of fusion (F) gene of hMPV - The positive samples detected by amplification of the $\mathrm{N}$ gene were submitted to amplification of the $\mathrm{F}$ gene to perform hMPV subtyping by genome sequencing.

RNA extracted as described above was reverse transcribed using the Superscript II RT enzyme (Invitrogen, Life Technologies) and random primer hexamers (Amersham Pharmacia Biotech). cDNA was amplified to detect a $450 \mathrm{bp}$ fragment of the F gene (positions 37284168 nt, based on sequence AY297749). Two microliters of cDNA were used for a $25 \mu \mathrm{L}$ reaction containing the following: $2.5 \mu \mathrm{L} 10 \times$ PCR buffer minus $\mathrm{Mg}$ (Invitrogen, Life Technologies, Carlsbad, CA), $0.75 \mu \mathrm{L}$ of $50 \mathrm{mM} \mathrm{MgCl}$ (Invitrogen, Life Technologies, Carlsbad, CA), $4 \mu \mathrm{L}$ of $2.5 \mathrm{mM}$ dNTPs, 10 pmol of FF1 (5'-CWTTRGACYTAATGACWGATG-3'), 10 pmol of RR1 (5'-GTCTTCCTGTGCTRACTTTG-3') primers (Kaida et al. 2006) and 1.25 U of Taq Polymerase (Invitrogen, Life Technologies, Carlsbad, CA) and the final volume was completed with RNase free distilled water. Cycling conditions were as follows: an initial denaturation step at $94^{\circ} \mathrm{C}$ for $3 \mathrm{~min}$, followed by 35 cycles at $94^{\circ} \mathrm{C}$ for $45 \mathrm{~s}$, $55^{\circ} \mathrm{C}$ for $30 \mathrm{~s}$ and $72^{\circ} \mathrm{C}$ for $45 \mathrm{~s}$ and a final extension at $72^{\circ} \mathrm{C}$ for $10 \mathrm{~min}$. PCR products were analyzed by electrophoresis in a $1 \%$ agarose gel stained with ethidium bromide. For reference and quality control, water was included as a negative control and a positive sample was confirmed by $\mathrm{N}$ amplification, as described.

Sequence comparisons and phylogenetic relationship - Purified PCR products obtained by N and/or F amplification were directly submitted to automated nucleotide sequencing with a BigDye Terminator v3.1 Cycle sequencing kit in an ABI genetic analyser 3130 (Applied Biosystems Inc, CA). The obtained sequences were submitted to GenBank (accessions HM124479-HM124528 and HM173093HM173096) and were analyzed with complete F and/or $\mathrm{N}$ sequences from GenBank database with following accessions: EU857607, EU857582, EU857572, EU857573, EU857548, EU857544, EU857553, EU857551, EU857566 and EU857564 for gene F, as described by Yang et al. (2009), and AY145285, AY145281, AY145280, AY145279, AY145274, AF371337, AY145277, AY525843, EU179266, AY145276, AY530095, AY145272 and AY145276 for gene $\mathrm{N}$, as described by Huck et al. (2006). For outgroups, an avian metapneumovirus type C EF199771 and EF199772 for gene F and AY590688 for gene $\mathrm{N}$ were used.

Sequences were aligned with ClustalW software and analyzed by similarity/identity calculations using BioEdit Sequence Alignment Editor software, version 7.0.0, and by the bootstrap neighbor-joining method $(2,000$ replicates) using the complete deletion and Kimura-2 parameters of the MEGA software package, version 4 (Kumar et al. 2004).

Clinical data - Demographic and clinical data were obtained from medical records and compared with subtyping results using Excel Microsoft. Statistical analyses were carried out using the Chi-square test or Fisher's exact test and were performed using Graph Pad Prism version 3.00 for Windows, GraphPad Software, San Diego, California, USA. In all of the analyses, a value of $p<$ 0.05 was considered statistically significant. 
Ethics - The study was approved by the Committee on the Ethics of Research on Human Beings of the HCUFPR (reference 0035.0.208.000-06).

\section{RESULTS}

The study was performed with 1,572 NPAs samples collected in the 2006-2008 period. The study involved 445, 527 and 600 samples collected from 2006-2008, respectively. Seven hundred twenty-three samples $(723 / 1572$, $46 \%)$ from pediatric inpatients, 356 (356/1572, 22.6\%) from patients submitted to HSCT and 493 (493/1572, $31.4 \%$ ) from outpatients were analyzed. A predominance of male patients $(592 / 1079,54.9 \%)$ from all clinical units $(p=0.048)$ was observed in the sample.

An RT-PCR assay for detection of the hMPV N gene was performed on all samples, and $61(3.9 \%)$ positive samples were detected. Fig. 1 shows the clinical unit distribution of the analyzed samples and hMPV positivity. The incidence of hMPV infection was higher in outpatients $(29 / 493,5.9 \%)$ than inpatients $(32 / 1079,3 \%)(\mathrm{p}=$ 0.0072). The age of the hMPV infected patients varied in the clinical units studied, as shown in Fig. 1. hMPV had a higher incidence in patients less than five years old $(39 / 61,63.9 \%)(\mathrm{p}=0.0093)$. Most $(36 / 61,59 \%)$ hMPV infected patients were female $(\mathrm{p}=0.08)$.

The incidence by year of hMPV was 3.1\% (14/445), $7 \%(37 / 527)$ and $1.7 \%(10 / 600)$, respectively, for 2006 , 2007 and 2008 (Table I). Most samples of hMPV detected in 2007 were obtained from outpatients (23/37, $62.2 \%$ ). Viral co-infections were found to occur mainly in children $(12 / 16,75 \%)$ with the mean age of $4.8 \pm 3.6$ months. The viruses detected as co-infections were RSV (7/16, 43.7\%), FLU A (4/16, 25\%), PIV3 (2/16, 12.5\%), $\operatorname{AdV}(2 / 16,12.5 \%)$ and FLU B $(1 / 16,6.25 \%)$. Only one patient (27 days-old) co-infected with RSV was hospitalized in an intensive care unit for 11 days because of bronchiolitis. Most hospitalized pediatric patients $(14 / 24,58 \%)$ were breastfed until either the time of infection or six months of age. Among the children that were co-infected with other viruses, only the child who was co-infected with AdV had not been breastfed.

Genotyping - Nucleotide sequences were obtained from 51 (51/61, 83.6\%) hMPV positive samples. PCR products were selected to submit to partial genome sequencing of the $\mathrm{F}$ and/or $\mathrm{N}$ gene to determine the hMPV subtype. Thirty-nine samples were sequenced for the $\mathrm{F}$ gene and 15 samples were sequenced for the $\mathrm{N}$ gene. Only in three samples were both genes sequenced. Eleven (11/14, 78.6\%) samples from 2006, 31 (31/37, 83.8\%) samples from 2007 and nine $(9 / 10,90 \%)$ samples from 2008 were sequenced.

hMPV subtype A1 was found in five (5/51, 9.8\%), A2a in nine (9/51, 17.6\%), B1 in $13(13 / 51,25.5 \%)$ and $\mathrm{B} 2$ in 24 (24/51, 47.1\%) samples. Subtypes A1, A2a, B1 and B2 showed, respectively, $95-99 \%, 96-99 \%, 92-99 \%$ and $94-$ $99 \%$ nucleotide similarity with the reference sequences for each of the previously described subtypes (data not shown). These results and the high bootstrap values in the phylogeny tree confirm the detected subtypes (Fig. 2).

hMPV circulation during the study period - Fig. 3 shows the distribution of the hMPV positive samples

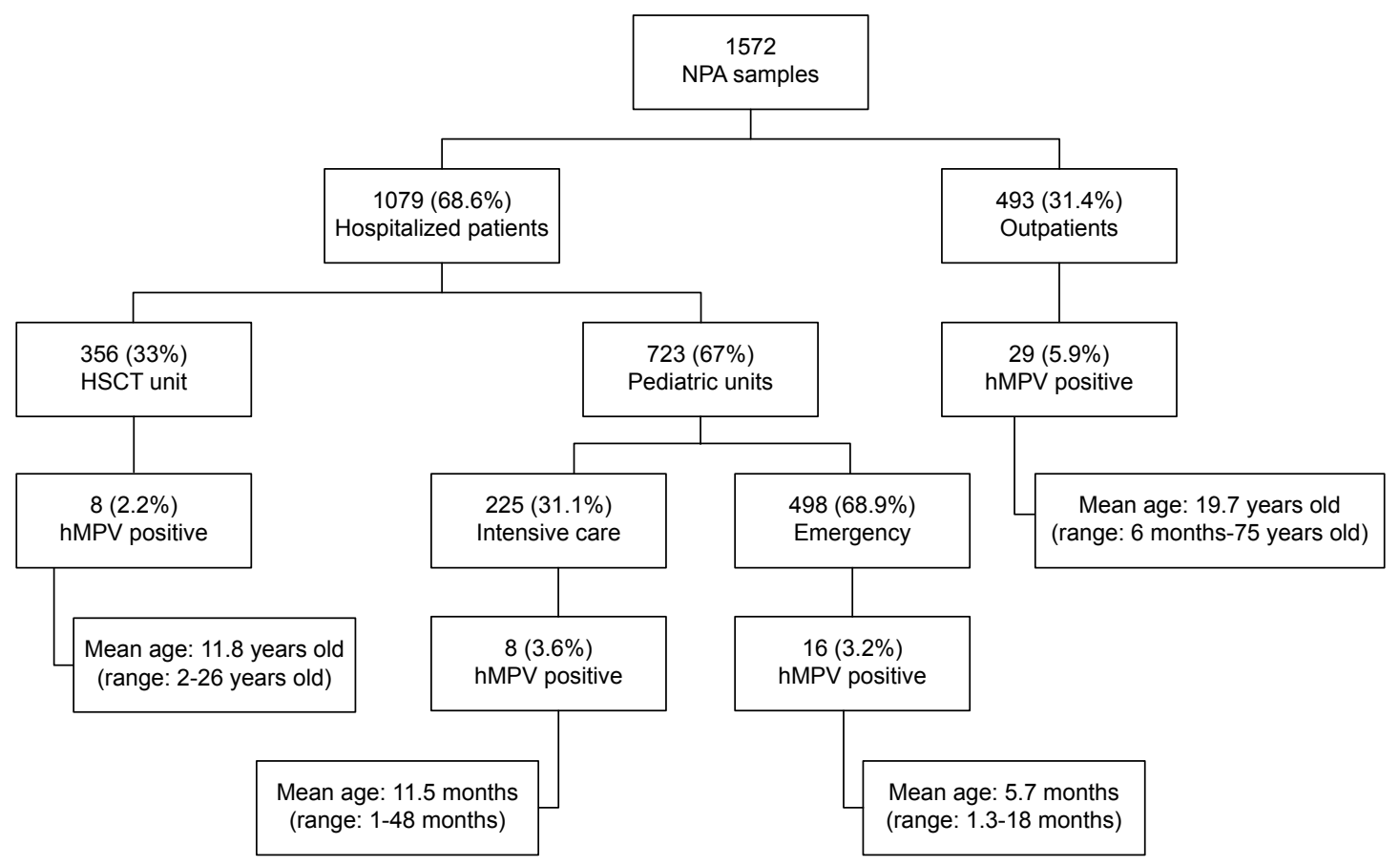

Fig. 1: clinical unit distribution of the nasopharyngeal aspirates (NPA) samples submitted to the virology laboratory for the detection of respiratory viruses; hMPV: human metapneumovirus; HSCT: Haematopoietic Stem Cell Transplantation. 


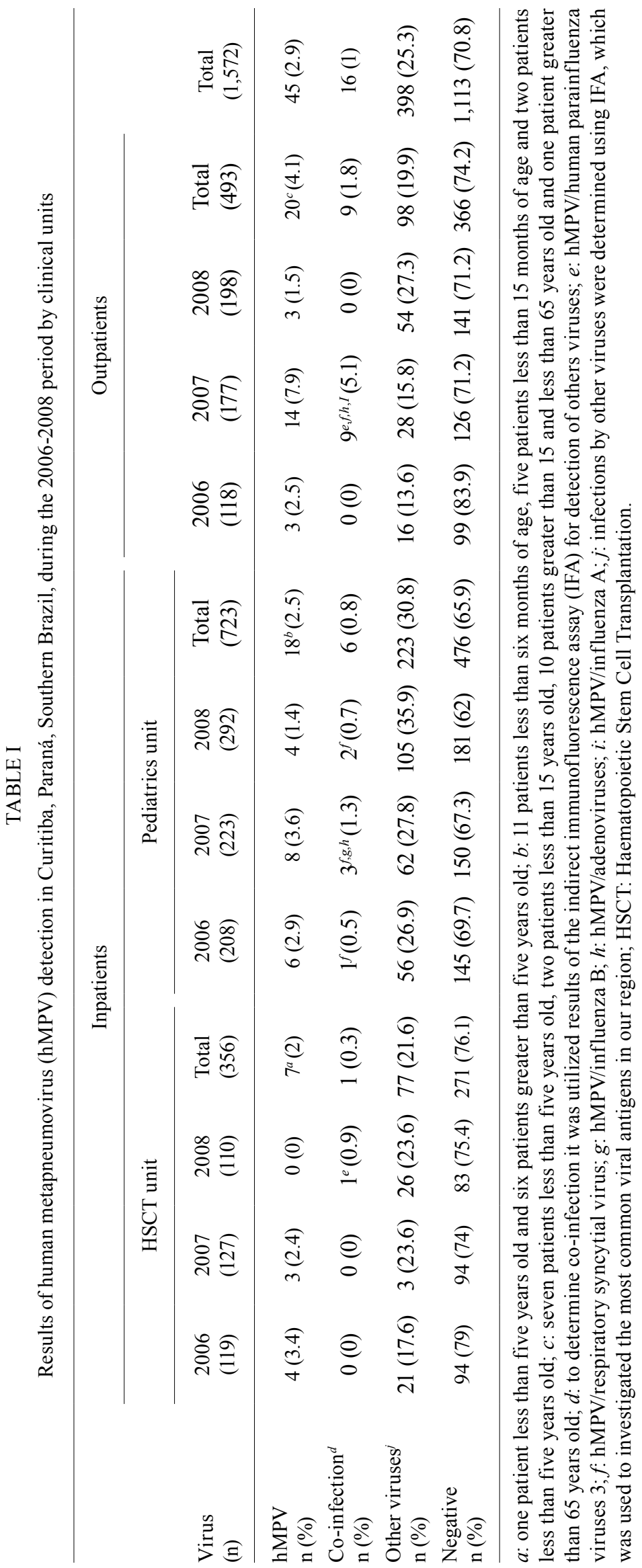




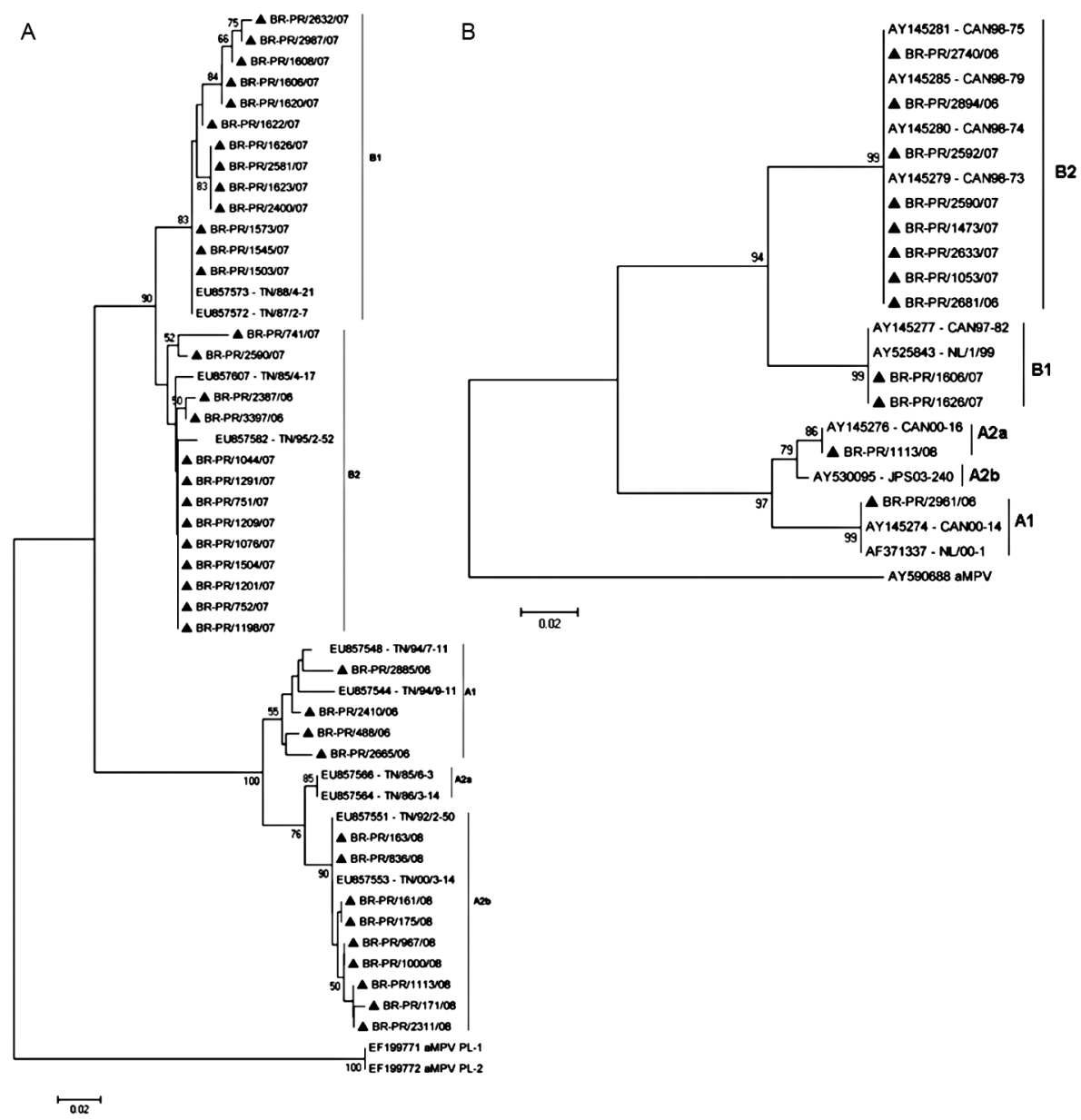

Fig. 2: a neighbor-joining tree resulting from the sequence analysis of human metapneumovirus from Curitiba, Paraná, during the 2006-2008 period and sequences retrieved from GenBank (see Patients, Materials and Methods) by MEGA version 4. A: partial fusion gene; B: partial nucleoprotein gene. The sequences of this study are dotted with a black triangle and named BR-PR followed by the number of the samples and year of the sample collection. Only bootstrap values higher than $50 \%$ are shown.

throughout the entire three year study period. It was found that hMPV circulated throughout the year with two annual peaks, one in the autumn and another in the late winter and spring. A higher incidence of hMPV (18/37, 48.6\%) was observed in May and June 2007. All genotypes (A and B) of hMPV were detected in the three years of the study. In 2006 and 2007, two hMPV subtypes co-circulated per year (A1/B2 and B1/B2, respectively). In 2008, only one subtype was detected (A2a). Subtype B2 showed higher circulation than other subtypes in the study period. The most common subtype within a one year period was found in both inpatients and outpatients.

Clinical findings - The respiratory symptoms frequently reported in pediatric inpatients were: dyspnea $(90.9 \%)$, cough $(86.3 \%)$, tachypnea $(77.3 \%)$, fever $(54.5 \%)$, wheeze $(54.5 \%)$, cyanosis $(50 \%)$, vomiting $(50 \%)$, apnea $(22.7 \%)$, rhinorrhea $(18.2 \%)$ and diarrhea $(9.1 \%)$. Pulse oximetry and $\mathrm{pCO}_{2}$ mean values at the moment the patients were admitted to hospital were $81.1 \pm 11.6 \%$ and $39.6 \pm 13.8 \mathrm{mmHg}$, respectively. Oxygen therapy was used in $20(90.9 \%) \mathrm{hMPV}$ infected patients for an average of $8.2 \pm 6.6$ days. Mechani-

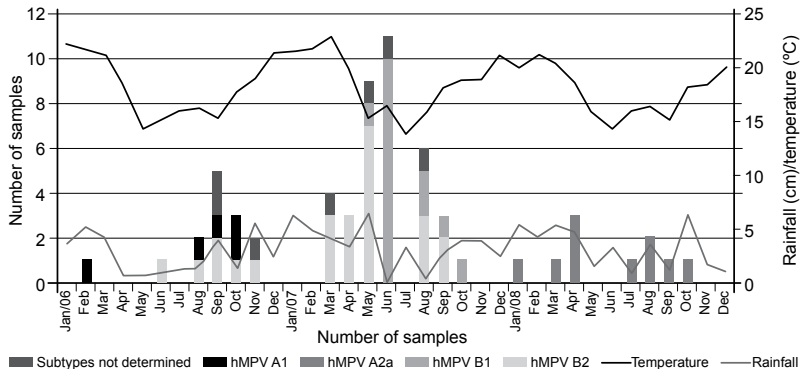

Fig. 3: distribution of human metapneumovirus (hMPV) positive samples and its relationship with the average daytime temperature and rainfall from January 2006-December 2008 in Curitiba, Paraná, Southern Brazil.

cal ventilation was necessary in five $(22.7 \%)$ patients for an average of $9.5 \pm 1.0$ days. Antibiotic therapy was used in $12(54.5 \%)$ patients for an average of $10.5 \pm 6.8$ days. Bronchodilator therapy was used in 16 (72.7\%) patients for 
an average of $5.5 \pm 2.7$ days. Corticoid therapy was used in eight (36.4\%) patients for an average of $5.0 \pm 3.8$ days. The most common diagnoses given were bronchiolitis (31.8\%), bronchopneumonia (18.2\%), trachiobronchitis (18.2\%), laryngotracheobronchitis $(9.1 \%)$, pneumonia $(9.1 \%)$ and acute respiratory insufficiency $(4.5 \%)$. Among the hMPV positive children, one $(4.5 \%)$ was premature and seven $(31.8 \%)$ were admitted to intensive care units. The duration of hospitalization of all positive patients ranged from 4-50 days, with an average of $15.0 \pm 16.9$ days.

Patients infected by hMPV and treated in the primary healthcare units had the following respiratory symptoms: rhinorrhea $(82.8 \%)$, cough $(79.3 \%)$, fever $(75.9 \%)$, dyspnea $(65.5 \%)$, headache $(48.3 \%)$, myalgia $(44.8 \%)$, pharyngitis $(37.9 \%)$ and otalgia $(20.7 \%)$. Antibiotic therapy was used in nine $(31 \%)$ patients for an average of $9.0 \pm 1.5$ days. Bronchodilator therapy was used in two (6.9\%) patients for an average of $4.0 \pm 1.4$ days. Corticoid therapy was not necessary. Only $11(11 / 29,37.9 \%)$ cases of hMPV infection related to a final diagnosis of respiratory condition were reported in the medical records and the most frequent ones were sinusitis (5/11, $45.5 \%)$, nasopharyngitis $(4 / 11,36.4 \%)$, bronchitis $(1 / 11$, $9.1 \%)$ and laryngopharyngitis $(1 / 11,9.1 \%)$.

Table II shows the clinical characteristics, treatment and diagnostic findings of the hMPV infected patients related to subtype. For both inpatients and those assisted in the primary healthcare service, there were no significant statistical differences among clinical characteristics, treatment and diagnostic findings for the different hMPV subtypes. One pediatric patient died due to complications associated with hMPV A2a infection. This patient was 5.1 months old, had Down syndrome, had been exposed to passive smoking and developed a secondary bacterial infection on the 23rd day of hospitalization, progressing to death from sepsis.

\section{DISCUSSION}

hMPV has been frequently identified as a virus associated with respiratory tract diseases worldwide (Howe 2002, Bastien et al. 2003, Cuevas et al. 2003, Freymouth et al. 2003, Madhi et al. 2003, Peiris et al. 2003, Rao et al. 2004, Mirazo et al. 2005, Gray et al. 2006). We retrospectively assessed the presence and clinical importance of hMPV infection as a unique pathogen that was detected in $2.9 \%$ of ARIs in a population from Curitiba. RT-PCR was used to amplify a $\mathrm{N}$ gene that can detect both hMPV genotypes (Biacchesi et al. 2003). This is the first study to describe the circulation of all hMPV genotypes in Southern Brazil.

Depending on the population studied, the prevalence of hMPV as a cause of ARI ranges from 1.5-41\% (Mahalingam et al. 2006). The present study included in and outpatients and the virus was present in 3\% and 5.9\% of the samples, respectively, which is similar to the results reported in other countries (Cuevas et al. 2003, Bouscambert-Duchamp et al. 2005, Chano et al. 2005).

Primary health care services had more cases of hMPV than HC-UFPR, particularly in 2007. Cuevas et al. (2003) also reported that hMPV was more prevalent in outpatients.
hMPV was responsible for ARIs in hospitalized children with a mean age of 7.6 months (Cuevas et al. 2003) and in patients treated in the primary healthcare service with a mean age of 19.7 years. According to the results of the present study, hMPV caused respiratory disease in all age groups (children, adults and elderly) (Rafiefard et al. 2008) and was more common in females (59\%). In contrast, some reports have shown that hMPV infection is more frequent in males than in females (Gray et al. 2006, Mahalingam et al. 2006).

Most reports show that hMPV co-infections may occur with other respiratory viruses, mainly hMPV/RSV (Cuevas et al. 2003, Greensill et al. 2003), and studies in which only previously negative samples were tested might underestimate the percentage of hMPV-positive samples (van den Hoogen et al. 2004). This study has shown hMPV co-infection with RSV, PIV3, FLU B, FLU $\mathrm{A}$ and AdV. hMPV/RSV was the most frequent (43.7\%) condition. Co-infections were more commonly found in children less than one year old (Aberle et al. 2005). Comparison between the children hospitalized for only hMPV infection and those with hMPV co-infections showed no significant differences in the clinical manifestations or in the final diagnosis (Xepapadaki et al. 2004).

Exact comparisons between the incidence of hMPV and other viruses in this study are difficult to make because hMPV was detected by a sensitive molecular technique, whereas other viruses were detected by IFA (Stempel et al. 2009). We believe that the detection of co-infections and incidence of others viruses may have been underestimated.

In Curitiba, during the coldest months of the year, an increased number of NPAs were collected (Tsuchiya et al. 2005). hMPV is related with winter months (Jartti et al. 2002, van den Hoogen et al. 2004, BouscambertDuchamp et al. 2005) and we report that this virus had two peaks in the year, one in the autumn and another in the late winter and spring, that correlated with lower temperature months in the region. In other Brazilian Regions, the presence of the hMPV correlates with rainy seasons, as reported by Cuevas et al. (2003), and with temperature decreases.

In May and June 2007, a higher incidence of hMPV (51.6\%) was reported, although the hMPV B2 circulated in May and the hMPV B1 subtype circulated in June. All genotypes (A and B) of hMPV were detected during the study period. Unlike Carneiro et al. (2009), we found that different genotypes can co-circulate during the same year, with A1 and B2 hMPV subtypes being detected in August, September and October 2006. Matsuzaki et al. (2008) and Oliveira et al. (2009) also reported the circulation of the A and B genotypes in 2006. Although the study was only conducted over three consecutive years, it was observed that at least two hMPV subtypes circulated in the same year and occurred in both 2006 and 2007. However, in $2008,90 \%$ of the hMPV detected were subtyped and only subtype A2a was identified. It was observed that the hMPV genotypes changed after a period of circulation (subtypes A1 and B2 in 2006; subtypes B2 and B1 in 2007 and subtype A2a in 2008) and that subtype A2a did not circulate in the previous years of this study, occur- 
TABLE II

Clinical characteristics, treatment and diagnosis from patients with different human metapneumovirus (hMPV) subtype infection

\begin{tabular}{|c|c|c|c|c|c|c|c|c|}
\hline \multirow[b]{2}{*}{ Subtype infection } & \multicolumn{4}{|c|}{$\begin{array}{l}\text { Inpatients } \\
\left(\mathrm{n}=26^{a}\right)\end{array}$} & \multicolumn{4}{|c|}{$\begin{array}{l}\text { Outpatients } \\
\qquad\left(\mathrm{n}=25^{a}\right)\end{array}$} \\
\hline & $\begin{array}{c}\mathrm{A} 1 \\
(\mathrm{n}=3)\end{array}$ & $\begin{array}{c}\mathrm{A} 2 \mathrm{a} \\
(\mathrm{n}=6)\end{array}$ & $\begin{array}{c}\mathrm{B} 1 \\
(\mathrm{n}=6)\end{array}$ & $\begin{array}{c}\text { B2 } \\
(n=11)\end{array}$ & $\begin{array}{c}\mathrm{A} 1 \\
(\mathrm{n}=2)\end{array}$ & $\begin{array}{l}\mathrm{A} 2 \mathrm{a} \\
(\mathrm{n}=3)\end{array}$ & $\begin{array}{c}\mathrm{B} 1 \\
(\mathrm{n}=7)\end{array}$ & $\begin{array}{c}\text { B2 } \\
(n=13)\end{array}$ \\
\hline Female n $(\%)$ & $3(100)$ & $4(66.7)$ & $4(66.7)$ & $6(54.5)$ & $1(50)$ & $1(33.3)$ & $6(85.7)$ & $7(53.8)$ \\
\hline Male n (\%) & $0(0)$ & $2(33.3)$ & $2(33.3)$ & $5(45.4)$ & $1(50)$ & $2(66.7)$ & $1(14.3)$ & $6(46.2)$ \\
\hline Age $($ median \pm SD) & $\begin{array}{c}2.1 \pm 0.1 \\
\text { months }\end{array}$ & $\begin{array}{c}2.8 \pm 3.6 \\
\text { months }\end{array}$ & $\begin{array}{c}14.0 \pm 10.7 \\
\text { months }\end{array}$ & $\begin{array}{c}3.4 \pm 3.9 \\
\text { months }\end{array}$ & $\begin{array}{l}41.9 \pm 47.4 \\
\text { years }\end{array}$ & $\begin{array}{l}26.6 \pm 21.0 \\
\text { years }\end{array}$ & $\begin{array}{c}34.9 \pm 20.9 \\
\text { years }\end{array}$ & $\begin{array}{c}11.7 \pm 14.6 \\
\text { years }\end{array}$ \\
\hline \multirow[t]{2}{*}{$\begin{array}{l}\text { Time of hospitalization } \\
\text { (median days } \pm \mathrm{SD} \text { ) }\end{array}$} & $13.0 \pm 13.0$ & $12.0 \pm 30.3$ & $3.5 \pm 7.3$ & $15.0 \pm 8.9$ & - & - & - & - \\
\hline & n $(\%)$ & $\mathrm{n}(\%)$ & $\mathrm{n}(\%)$ & n $(\%)$ & $\mathrm{n}(\%)$ & n $(\%)$ & $\mathrm{n}(\%)$ & $\mathrm{n}(\%)$ \\
\hline \multicolumn{9}{|l|}{ Symptoms } \\
\hline Dyspnea & $1(33.3)$ & $6(100)$ & $5(83.3)$ & $9(81.8)$ & $1(50)$ & $3(100)$ & $3(42.8)$ & $9(69.2)$ \\
\hline Wheeze & $1(33.3)$ & $6(100)$ & $1(16.7)$ & $3(27.3)$ & 0 & 0 & 0 & $2(15.4)$ \\
\hline Cough & $3(100)$ & $5(83.3)$ & $5(83.3)$ & $10(90.9)$ & $2(100)$ & $3(100)$ & $2(28.6)$ & $12(92.3)$ \\
\hline Fever & $1(33.3)$ & $4(66.7)$ & $2(33.3)$ & $7(63.6)$ & $1(50)$ & $2(66.7)$ & $3(42.8)$ & $12(92.3)$ \\
\hline Rhinorrhea & $2(66.7)$ & $2(33.3)$ & 0 & $3(27.3)$ & $2(100)$ & $3(100)$ & $3(42.8)$ & $12(92.3)$ \\
\hline Apnea & 0 & $2(33.3)$ & $1(16.7)$ & $2(18.2)$ & 0 & 0 & 0 & 0 \\
\hline Cyanosis & $1(33.3)$ & $4(66.7)$ & $1(16.7)$ & $5(45.4)$ & 0 & 0 & 0 & 0 \\
\hline Vomiting & $2(66.7)$ & $3(50)$ & $2(33.3)$ & $4(36.4)$ & 0 & 0 & 0 & $1(7.7)$ \\
\hline Tachypnea & $2(66.7)$ & $6(100)$ & $3(50)$ & $6(54.5)$ & 0 & 0 & 0 & 0 \\
\hline Headache $^{b}$ & - & - & - & - & $1(50)$ & $3(100)$ & $3(42.8)$ & $4(30.8)$ \\
\hline Myalgia $^{b}$ & - & - & - & - & 0 & $3(100)$ & $3(42.8)$ & $4(30.8)$ \\
\hline Pharyngitis $^{b}$ & - & - & - & - & $1(50)$ & $2(66.7)$ & $1(14.3)$ & $5(38.5)$ \\
\hline Otalgy $^{b}$ & - & - & - & - & 0 & $1(33.3)$ & 0 & $4(30.8)$ \\
\hline \multicolumn{9}{|l|}{ Treatment } \\
\hline Admitted to ICU & $1(33.3)$ & $3(50)$ & $1(16.7)$ & $3(27.3)$ & - & - & - & - \\
\hline Oxygen therapies & $2(66.7)$ & $4(66.7)$ & $5(83.3)$ & $9(81.8)$ & - & - & - & - \\
\hline $\begin{array}{l}\text { Mechanical ventilatory } \\
\text { support }\end{array}$ & $1(33.3)$ & $2(33.3)$ & 0 & $3(27.3)$ & - & - & - & - \\
\hline Antibiotics use & $2(66.7)$ & $4(66.7)$ & $2(33.3)$ & $6(54.5)$ & 0 & 0 & 0 & $5(38.5)$ \\
\hline Inhaler therapies & $2(66.7)$ & $5(83.3)$ & $4(66.7)$ & $7(63.6)$ & 0 & 0 & 0 & $3(23.1)$ \\
\hline Bronchodilators use & $1(33.3)$ & $3(50)$ & $5(83.3)$ & $8(72.7)$ & 0 & 0 & 0 & $2(15.4)$ \\
\hline Corticoid use & $1(33.3)$ & $2(33.3)$ & $2(33.3)$ & $4(36.4)$ & 0 & 0 & 0 & 0 \\
\hline \multicolumn{9}{|l|}{ Diagnosis } \\
\hline $\begin{array}{l}\text { Acute respiratory } \\
\text { insufficiency }\end{array}$ & $0(0)$ & $1(16.7)$ & $0(0)$ & $0(0)$ & $0(0)$ & $0(0)$ & $0(0)$ & $0(0)$ \\
\hline Bronchiolitis & $0(0)$ & $4(66.7)$ & $2(33.3)$ & $0(0)$ & $0(0)$ & $0(0)$ & $0(0)$ & $0(0)$ \\
\hline Pneumonia & $0(0)$ & $1(16.7)$ & $1(16.7)$ & $1(9.1)$ & $0(0)$ & $0(0)$ & $0(0)$ & $0(0)$ \\
\hline Laryngotracheobronchitis & $1(33.3)$ & $0(0)$ & $0(0)$ & $1(9.1)$ & $0(0)$ & $0(0)$ & $0(0)$ & $0(0)$ \\
\hline Bronchopneumonia & $0(0)$ & $0(0)$ & $0(0)$ & $5(45.4)$ & $0(0)$ & $0(0)$ & $0(0)$ & $0(0)$ \\
\hline Trachiobronchitis & $0(0)$ & $0(0)$ & $2(33.3)$ & $2(18.2)$ & $0(0)$ & $0(0)$ & $0(0)$ & $0(0)$ \\
\hline Nasopharyngitis & $0(0)$ & $0(0)$ & $0(0)$ & $0(0)$ & $1(50)$ & $1(33.3)$ & $1(14.3)$ & $1(7.7)$ \\
\hline Laryngopharyngitis & $0(0)$ & $0(0)$ & $0(0)$ & $0(0)$ & $0(0)$ & $0(0)$ & $0(0)$ & $1(7.7)$ \\
\hline Bronchitis & $0(0)$ & $0(0)$ & $0(0)$ & $0(0)$ & $0(0)$ & $0(0)$ & $0(0)$ & $1(7.7)$ \\
\hline Sinusitis & $0(0)$ & $0(0)$ & $0(0)$ & $0(0)$ & $0(0)$ & $0(0)$ & $2(28.6)$ & $3(23.1)$ \\
\hline None diagnosis & $2(66.7)$ & $0(0)$ & $1(16.7)$ & $2(18.2)$ & $1(50)$ & $2(66.7)$ & $6(85.7)$ & $7(53.8)$ \\
\hline
\end{tabular}

$a$ : considered only the cases hMPV subtyped; $b$ : these symptoms are difficult to analyze in children less than one year old; ICU: intensive care unit; SD: standard deviation. Data are number of cases (\%), unless otherwise indicated. 
ring only in 2008. A periodical change in the predominant hMPV genotype/subtype has been previously reported, suggesting that antigenic shift may play a role as a mechanism of immune evasion (Larcher et al. 2008). Matsuzaki et al. (2008) explain that the predominant genotype and the most affected age group may be closely related to genotype-specific immune status within a community.

Boivin et al. (2004) have reported that in children less than three years, the hMPV genotype A is three times more common than genotype B (Boivin et al. 2004). In addition, group $B$ strains occurred more frequently in adults. Rafiefard et al. (2008) reported that genotype A was dominant in both age groups. In the present study, genotype $\mathrm{B}$ was prevalent in both age groups. The different results obtained by the referred studies can be explained by the dynamic fluctuations of the two genotypes in different countries/continents (Rafiefard et al. 2008). During the study period, genotype B was the most detected (73\%).

Symptoms of hMPV infection were similar to previous reports (Cuevas et al. 2003, Boivin et al. 2004, Chano et al. 2005). The final diagnosis showed that this virus was associated with lower respiratory tract disease (bronchiolitis, laryngotracheobronchitis and bronchopneumonia) that may cause an influenza-like illness in pediatric patients and in the adult population (Falsey et al. 2003, Xepapadaki et al. 2004, Bouscambert-Duchamp et al. 2005, Rafiefard et al. 2008). Among the hMPV infected patients submitted to HSCT proceedings, their underlying conditions may have contributed to their hospitalization and, in some cases, to the progression to a lower respiratory tract infection (Debur et al. 2010).

Previous reports that described the relationship between hMPV genotype and disease severity found no difference in clinical progression (Vicente et al. 2006, Agapov et al. 2006, Matsuzaki et al. 2008). Similarly, no correlation was observed between viral subtype and disease severity in the analyzed samples. However, a lower number of each hMPV subtype was detected in this study. Further studies comparing more cases are needed to clarify whether the hMPV subtype can be related to the severity of the infection or not. We suggest that hMPV infection should be routinely investigated in inpatients of all age groups to determine the risk of progressing to complications due to the occurrence of a lower respiratory tract infection.

In conclusion, $\mathrm{hMPV}$ has been reported as a respiratory pathogen in all age groups. Both hMPV genotypes can circulate in a single season and the predominant subtype switches in successive seasons. The disease severity did not correlate with hMPV subtype in the analyzed samples. Further studies, including analyzing additional consecutive years, are needed to determine the rule of hMPV genotypes/subtypes and to determine their pathogenicity.

\section{ACKNOWLEDGEMENTS}

To SIMEPAR (Meteorological Agency of Paraná State), for providing the environmental data of rainfall and temperature used in this study.

\section{REFERENCES}

Aberle JH, Aberle SW, Pracher E, Hutter HP, Kundi M, PopowKraupp T 2005. Single versus dual respiratory virus infections in hospitalized infants: impact on clinical course of disease and interferon-gamma response. Pediatr Infect Dis $J$ 24: 605-610.

Agapov E, Sumino KC, Gaudreault-Keener M, Storch GA, Holtzman MJ 2006. Genetic variability of human metapneumovirus infection: evidence of a shift in viral genotype without a change in illness. J Infect Dis 193: 396-403.

Alto WA 2004. Human metapneumovirus: a newly described respiratory tract pathogen. J Am Board Fam Pract 17: 466-469.

Bastien N, Normand S, Taylor T, Ward D, Peret TC, Boivin G, Anderson LJ, Li Y 2003. Sequence analysis of the N, P, M and $\mathrm{F}$ genes of Canadian human metapneumovirus strains. Virus Res 93: 51-62.

Biacchesi S, Skiadopoulos MH, Boivin G, Hanson CT, Murphy BR, Collins PL, Buchholz UJ 2003. Genetic diversity between human metapneumovirus subgroups. Virology 315: 1-9.

Boivin G, Abed Y, Pelletier G, Ruel L, Moisan D, Côté S, Peret TC, Erdman DD, Anderson LJ 2002. Virological features and clinical manifestations associated with human metapneumovirus: a new paramyxovirus responsible for acute respiratory-tract infections in all age groups. J Infect Dis 186: 1330-1334.

Boivin G, Mackay I, Sloots TP, Madhi S, Freymuth F, Wolf D, Shemer-Avni Y, Ludewick H, Gray GC, LeBlanc E 2004. Global genetic diversity of human metapneumovirus fusion gene. Emerg Infect Dis 10: 1154-1157.

Bouscambert-Duchamp M, Lina B, Trompette A, Moret H, Motte J, Andreoletti L 2005. Detection of human metapneumovirus RNA sequences in nasopharyngeal aspirates of young French children with acute bronchiolitis by real-time reverse transcriptase PCR and phylogenetic analysis. J Clin Microbiol 43: 1411-1414.

Calicó I, Lowak M, Bas A, Betbesé MT, Fuentes F, Loaiza N 2009. A comparative study of direct immunofluorescence, enzyme immunoassay and culture for diagnosing metapneumovirus infection. Enferm Infecc Microbiol Clin 27: 322-325.

Carneiro BM, Yokosawa J, Arbiza J, Costa LF, Mirazo S, Nepomuceno LL, Oliveira TF, Goulart LR, Vieira CU, Freitas GR, Paula NT, Queiróz DA 2009. Detection of all four human metapneumovirus subtypes in nasopharyngeal specimens from children with respiratory disease in Uberlândia, Brazil. J Med Virol 81: $1814-1818$

Casas I, Powell L, Klapper PE, Cleator GM 1995. New method for the extraction of viral RNA and DNA from cerebrospinal fluid for use in the polymerase chain reaction assay. $J$ Virol Methods 53: 25-36.

Chano F, Rousseau C, Laferrière C, Couillard M, Charest H 2005. Epidemiological survey of human metapneumovirus infection in a large pediatric tertiary care center. J Clin Microbiol 43: 5520-5525.

Costa LF, Yokosawa J, Mantese OC, Oliveira TFM, Silveira HL, Nepomuceno LL, Moreira LS, Dyonisio G, Rossi LMG, Oliveira RC, Ribeiro LZG, Queiróz DAO 2006. Respiratory viruses in children younger than five years old with acute respiratory disease from 2001 to 2004 in Uberlândia, MG, Brazil. Mem Inst Oswaldo Cruz 101: 301-306.

Cox MJ, Azevedo RS, Cane PA, Massad E, Medley GF 1998. Seroepidemiological study of respiratory syncytial virus in São Paulo state, Brazil. J Med Virol 55: 234-239.

Cuevas LE, Nasser AM, Dove W, Gurgel RQ, Greensill J, Hart CA 2003. Human metapneumovirus and respiratory syncytial virus, Brazil. Emerg Infect Dis 9: 1626-1628.

Debur MC, Bordignon J, Duarte dos Santos CN, Vidal LR, Nogueira MB, de Almeida SM, Raboni SM 2007. Acute respiratory infec- 
tion by human metapneumovirus in children in Southern Brazil. J Clin Virol 39: 59-62.

Debur MC, Vidal LR, Stroparo E, Nogueira MB, Almeida SM, Takahashi GA, Rotta I, Pereira LA, Silveira CS, Bonfim CM, Raboni SM 2010. Human metapneumovirus infection in hematopoietic stem cell transplant recipients. Transpl Infect Dis 12: 173-179.

Ebihara T, Endo R, Ishiguro N, Nakayama T, Sawada H, Kikuta H 2004. Early reinfection with human metapneumovirus in an infant. J Clin Microbiol 42: 5944-5946.

Esper F, Boucher D, Weibel C, Martinello RA, Kahn JS 2003. Human metapneumovirus infection in the United States: clinical manifestations associated with a newly emerging respiratory infection in children. Pediatrics 111: 1407-1410.

Falsey AR, Erdman D, Anderson LJ, Walsh EE 2003. Human metapneumovirus infections in young and elderly adults. $J$ Infect Dis 187: 785-790.

Freymouth F, Vabret A, Legrand L, Eterradossi N, Lafay-Delaire F, Brouard J, Guillois B 2003. Presence of the new human metapneumovirus in French children with bronchiolitis. Pediatr Infect Dis J 22: 92-94.

Gardner PS, McQuillin J 1968. Application of immunofluorescent antibody technique in rapid diagnosis of respiratory syncytial virus infection. Br Med J 3: 340-343.

Gray GC, Capuano AW, Setterquist SF, Sanchez JL, Neville JS, Olson J, Lebeck MG, McCarthy T, Abed Y, Boivin G 2006. Human metapneumovirus, Peru. Emerg Infect Dis 12: 347-350.

Greensill J, McNamara PS, Dove W, Flanagan B, Smyth RL, Hart CA 2003. Human metapneumovirus in severe respiratory syncytial virus bronchiolitis. Emerg Infect Dis 9: 372-375.

Howe M 2002. Australian find suggests worldwide reach for metapneumovirus. Lancet Infect Dis 2: 202 .

Huck B, Scharf G, Neumann-Haefelin D, Puppe W, Weigl J, Falcone V 2006. Novel human metapneumovirus sublineage. Emerg Infect Dis 12: 147-150.

Jartti T, van den Hoogen B, Garofalo RP, Osterhaus AD, Ruuskanen O 2002. Metapneumovirus and acute wheezing in children. Lancet 360: 1393-1394.

Kahn JS 2006. Epidemiology of human metapneumovirus. Clin Microbiol Rev 19: 546-557.

Kaida A, Iritani N, Kubo H, Shiomi M, Kohdera U, Murakami T 2006. Seasonal distribution and phylogenetic analysis of human metapneumovirus among children in Osaka City, Japan. $J$ Clin Virol 35: 394-399.

Kumar S, Tamura K, Nei M 2004. MEGA3: Integrated Software for Molecular Evolutionary Genetics Analysis and sequence alignment. Brief Bioinform 5: 150-163.

Larcher C, Pagani E, Rossi P, Amato B, Pescollderungg L, Campanini G, Percivalle E, Huemer HP 2008. Comparison of human metapneumovirus genotypes from the province of Bolzano in northern Italy with strains from surrounding regions in Italy and Austria. Jpn J Infect Dis 61: 154-156.

Mackay IM, Jacob KC, Woolhouse D, Waller K, Syrmis MW, Whiley DM, Siebert DJ, Nissen M, Sloots TP 2003. Molecular assays for detection of human metapneumovirus. J Clin Microbiol 41: 100-105.

Madhi SA, Ludewick H, Abed Y, Klugman KP, Boivin G 2003. Human metapneumovirus-associated lower respiratory tract infections among hospitalized human immunodeficiency virus type 1 (HIV-1)-infected and HIV-1-uninfected African infants. Clin Infect Dis 37: 1705-1710.
Maggi F, Pifferi M, Vatteroni M, Fornai C, Tempestini E, Anzilotti S, Lanini L, Andreoli E, Ragazzo V, Pistello M, Specter S, Bendinelli M 2003. Human metapneumovirus associated with respiratory tract infections in a 3-year study of nasal swabs from infants in Italy. J Clin Microbiol 41: 2987-2991.

Mahalingam S, Schwarze J, Zaid A, Nissen M, Sloots T, Tauro S, Storer J, Alvarez R, Tripp RA 2006. Perspective on the host response to human metapneumovirus infection: what can we learn from respiratory syncytial virus infections? Microbes Infect 8: 285-293.

Matsuzaki Y, Itagaki T, Abiko C, Aoki Y, Suto A, Mizuta K 2008. Clinical impact of human metapneumovirus genotypes and genotype-specific seroprevalence in Yamagata, Japan. J Med Virol 80: $1084-1089$

Mirazo S, Ruchansky D, Blanc A, Arbiza J 2005. Serologic evidence of human metapneumovirus circulation in Uruguay. Mem Inst Oswaldo Cruz 100: 715-718.

Oliveira DB, Durigon EL, Carvalho AC, Leal AL, Souza TS, Thomazelli LM, Moraes CT, Vieira SE, Gilio AE, Stewien KE 2009. Epidemiology and genetic variability of human metapneumovirus during a 4-year-long study in Southeastern Brazil. J Med Virol 81: 915-921.

Peiris JS, Tang WH, Chan KH, Khong PL, Guan Y, Lau YL, Chiu SS 2003. Children with respiratory disease associated with metapneumovirus in Hong Kong. Emerg Infect Dis 9: 628-633.

Rafiefard F, Yun Z, Orvell C 2008. Epidemiologic characteristics and seasonal distribution of human metapneumovirus infections in five epidemic seasons in Stockholm, Sweden, 2002-2006. J Med Virol 80: 1631-1638.

Rao BL, Gandhe SS, Pawar SD, Arankalle VA, Shah SC, Kinikar AA 2004. First detection of human metapneumovirus in children with acute respiratory infection in India: a preliminary report. J Clin Microbiol 42: 5961-5962.

Stempel HE, Martin ET, Kuypers J, Englund JA, Zerr DM 2009. Multiple viral respiratory pathogens in children with bronchiolitis. Acta Paediatr 98: 123-126.

Thomazelli LM, Vieira S, Leal AL, Sousa TS, Oliveira DB, Golono MA, Gillio AE, Stwien KE, Erdman DD, Durigon EL 2007. Surveillance of eight respiratory viruses in clinical samples of pediatric patients in Southeast Brazil. J Pediatr (Rio J) 83: 422-428.

Tsuchiya LR, Costa LM, Raboni SM, Nogueira MB, Pereira LA, Rotta I, Takahashi GR, Coelho M, Siqueira MM 2005. Viral respiratory infection in Curitiba, Southern Brazil. J Infect 51: 401-407.

van den Hoogen BG, de Jong JC, Groen J, Kuiken T, de Groot R, Fouchier RA, Osterhaus AD 2001. A newly discovered human pneumovirus isolated from young children with respiratory tract disease. Nat Med 7: 719-724.

van den Hoogen BG, Osterhaus DM, Fouchier RA 2004. Clinical impact and diagnosis of human metapneumovirus infection. $\mathrm{Pe}$ diatr Infect Dis J 23 (Suppl. 1): S25-32.

Vicente D, Montes M, Cilla G, Perez-Yarza EG, Perez-Trallero E 2006. Differences in clinical severity between genotype A and genotype B human metapneumovirus infection in children. Clin Infect Dis 42: e111-113.

Xepapadaki P, Psarras S, Bossios A, Tsolia M, Gourgiotis D, LiapiAdamidou G, Constantopoulos AG, Kafetzis D, Papadopoulos NG 2004. Human metapneumovirus as a causative agent of acute bronchiolitis in infants. J Clin Virol 30: 267-270.

Yang CF, Wang CK, Tollefson SJ, Piyaratna R, Lintao LD, Chu M, Liem A, Mark M, Spaete RR, Crowe JE Jr, Williams JV 2009. Genetic diversity and evolution of human metapneumovirus fusion protein over twenty years. Virol J 6: 138. 